\title{
Antimicrobial Effect of Acidified Sodium Chlonite (ASC) on Whole Croaker
}

\author{
Byung-Doo Lee ${ }^{1}$, Jaheon Koo ${ }^{2}$, Michael L. Jahncke ${ }^{3}$, Duwoon Kim", \\ Dong-Ok Chung, and Jong-Bang Eun $^{1 \dagger}$ \\ ${ }^{1}$ Department of Food Science and Technology and Institute of Agricultural Science and Technology, \\ Chonnam National University, Gwangju 500-757, Korea \\ ${ }^{2}$ Department of Agriculture/Regulatory Science, University of Arkansas at Pine Bluff, Pine Bluff, Arkansas 71601, USA \\ ${ }^{3}$ Virginia Seafood Agricultural Research and Extension Center, Hampton, VA 23669, USA \\ ${ }^{4}$ Department of Food and Nutrition, Chonnam National University, Jeonnam 550-749, Korea \\ ${ }^{5}$ Department of Culinary Art, Chodang University, Jeonnam 534-701, Korea
}

\begin{abstract}
The antimicrobial effect of acidified sodium chlonite (ASC) solution on whole croaker skin was evaluated. Whole croaker skin was treated with ASC (50, 100, 200, 400, and 600 ppm) and distilled water. After 10-minute exposure to $600 \mathrm{ppm}$ ASC, 8\% of Gram-negative bacteria survived on the whole croaker sample. Treatment with $50 \mathrm{ppm}$ ASC eliminated all colifoms in the initial load. Immersion treatment with 600 ppm ASC resulted in $1.3 \mathrm{log} \mathrm{CFU} / \mathrm{cm}^{2}$ greater kill of the initial mesophile loads of control $\left(2.8 \mathrm{log} \mathrm{CFU} / \mathrm{cm}^{2}\right)$ than distilled water. Fifty ppm ASC solution produced a 1.6-log reduction of psychrotrophic bacteria. ASC treatment was an effective method for reducing naturally occuming microflora on whole croaker skin.
\end{abstract}

Key words: croaker, acidified sodium chlorite (ASC)

\section{INTRODUCTION}

Seafood and meat products are perishable because these foods provide rich sources of nutrients and favorable habitats for microorganisms in their tissues (1). This environment may cause wounding, enabling pathogenic bacteria to pass through the skin barrier $(2,3)$. However, an increasing number of pathogen outbreaks have resulted in fish losses in aquaculture and related fields despite the use of antibiotics and vaccinations to control microorganisms (4).

Recently, the Food and Drug Administration (FDA) has approved the use of ASC on seafood. The potential application of ASC to meats, poultry, fermented Chinese cabbage and seafood has been widely investigated (5-7). The antimicrobial activity of ASC to control Listeria monocytogenes on the skin of whole salmon was tested (8). ASC was also used in a mouth rinse with anti-plaque activity and reduced the Staphylococcus aureus counts (9). The post-chill dip application using ASC was assessed for its ability to reduce the number of Campylobacter spp. and Escherichia coli in commercial broiler (10). Through continuing efforts, food industries have developed new pathogen-controlling compositions such as cetylpyridinium chloride, acidified sodium chlorite and activated lactoferrin to effectively decontaminate seafood and meat products (11-13). Both the USDA and the FDA have approved ASC for its use as an antimicrobial intervention on red meat, poultry, seafood, and fruits and vegetables by either spray or dip application $(11,12)$. ASC sprays effectively decontaminate meat and poultry carcass surfaces (14). ASC works in aqueous solution by breaking sulfide and disulfide linkages and attacking bacterial cell components non-specifically (11). In this study, we evaluated the efficacy of ASC as a disinfectant treatment on the skin of whole croaker.

\section{MATERIALS AND METHODS}

Preparation of acidified sodium chlonite (ASC)

The active ingredients of acidified sodium chlorite were obtained from Alcide Corporation $(\mathrm{pH}$ 2.5, Redmond, WA, USA). ASC solution consisted of 1.7 g citric acid and $100 \mathrm{~mL}$ of sodium chlorite solution ( $\mathrm{pH}$ 2.9). ASC solution was diluted with distilled water to a final concentration of 50,100, 200, 400, and 600 ppm (pH 3.16 to 3.78).

\section{Sample treatment}

Fresh whole Atlantic croaker (Micropogonias undulates) (length: 208.58 $\pm 44.68 \mathrm{~cm}$; weight: 25.09 \pm $1.45 \mathrm{~g}$ ) were purchased from a local seafood retail store. Whole croaker was dipped into various concentrations of ASC solution for 5 or $10 \mathrm{~min}$, and then fish samples 
were drained to remove any excess ASC solution. Samples were placed on a polystyrene tray and wrapped in PVDC film. Fish fillets in the control group were left untreated.

\section{Microbiological analysis}

A template area $\left(1 \mathrm{~cm}^{2}\right)$ on the surface of whole croaker skin was swabbed with a sterile cotton swab. The swab was vortex-mixed for $1 \mathrm{~min}$ in $0.1 \%$ peptone solution ( $\mathrm{pH}$ 7.2). The peptone solution was serially diluted and plated on plate count agar (PCA) (Difco Laboratories, Detroit, MI, USA). Plates were incubated at $37^{\circ} \mathrm{C}$ for $48 \mathrm{hrs}$ (4). The fillet sample (60 g) was blended with $540 \mathrm{~mL}$ of $0.1 \%$ peptone solution in a stomacher (Seward model 400, Tekmar Company, Cincinnati, OH, USA) for $2 \mathrm{~min}$, and then the homogenized solution was plated on PCA. Plates were incubated at $4^{\circ} \mathrm{C}$ for 7 days for psychrotrophic plate counts (PPC) and at $37^{\circ} \mathrm{C}$ for 2 days for mesophilic plate counts (MPC), respectively. Plate counts of Gram-negative bacteria were determined on violet red bile agar (VRBA) and on PCA supplemented with $0.1 \%$ crystal violet and 2,3,5-triphenyltetrazolium chloride, respectively. Plates were incubated at $37^{\circ} \mathrm{C}$ for 2 days. Each treatment was tested in four replications with duplicate samples.

\section{RESULTS AND DISCUSSION}

Counts of Gram-negative bacteria on whole croaker skin were compared after treatment with ASC solution and distilled water for 5 or $10 \mathrm{~min}$ (Fig. 1). Treatment with $600 \mathrm{ppm}$ ASC for 5 min achieved a 1.3-log reduction in the numbers of Gram-negative bacteria compared with samples treated with distilled water or control samples. Five- and 10-minute exposures to increasing concentrations of ASC further reduced the numbers. After 10-min exposure to 600 ppm ASC, 8\% of Gram-

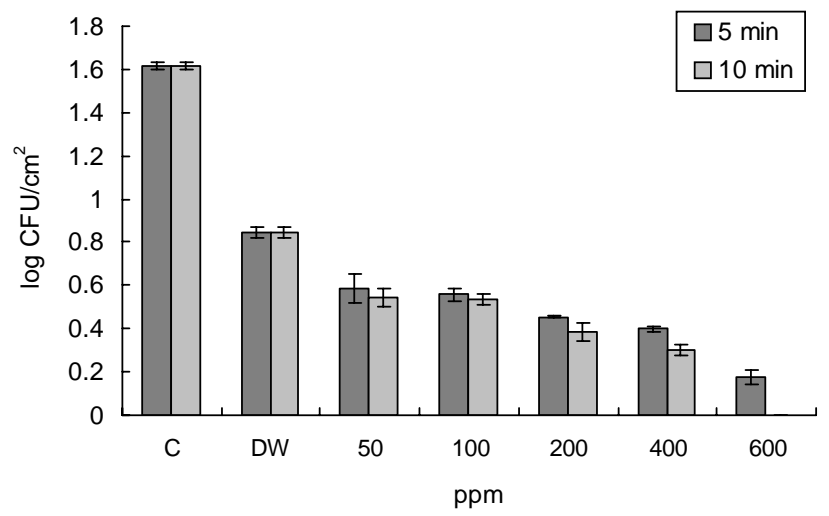

Fig. 1. Immersion tests against Gram-negative bacteria on whole croaker dipped in acidified sodium chlorite solution for 5 or 10 minutes. negative bacteria survived on croaker sample compared with the control sample, while $56 \%$ of Gram-negative bacteria survived after 10-min treatment with distilled water.

The effectiveness of ASC against mesophiles on whole croaker skin was compared with that of distilled water (Fig. 2). Compared with the MPC (2.8 log $\mathrm{CFU} / \mathrm{cm}^{2}$ ) of the control samples, $600 \mathrm{ppm}$ ASC reduced MPC by $1.3-\log \mathrm{CFU} / \mathrm{cm}^{2}$ after 5- or 10-min exposure, showing about $1.8 \log \mathrm{CFU} / \mathrm{cm}^{2}$ greater kill than distilled water. After 10-min exposure to $600 \mathrm{ppm}$ ASC, 46\% of mesophiles survived on the whole croaker sample compared with the control sample, while $54 \%$ of mesophiles survived after treatment with distilled water. There was little difference in MPC between 5-min and 10-min exposure to ASC.

The effectiveness of ASC against psychrotrophs on whole croaker was compared with that of distilled water (Fig. 3). ASC treatment reduced PPC by more than 1 log. Exposure to $600 \mathrm{ppm}$ ASC for 10 min reduced PPC by $0.4 \log \mathrm{CFU} / \mathrm{cm}^{2}$. PPC was reduced by more than

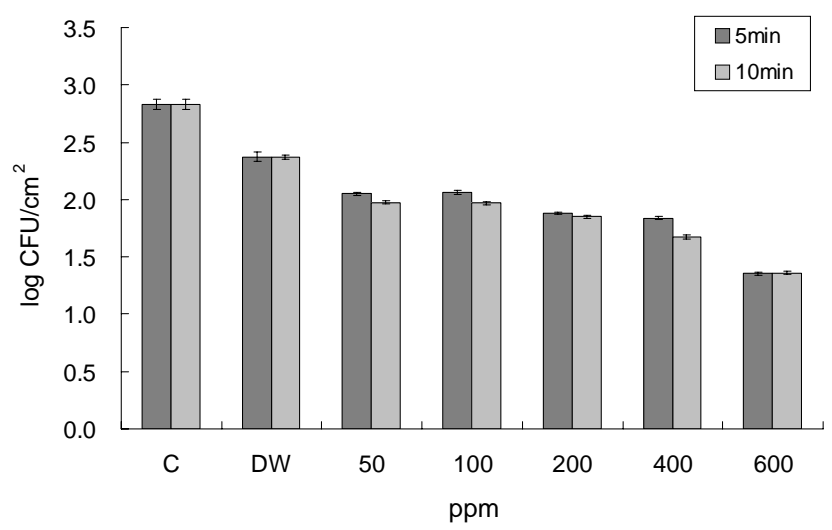

Fig. 2. Immersion tests against mesophiles on whole croaker dipped in acidified sodium chlorite solution for 5 or 10 minutes.

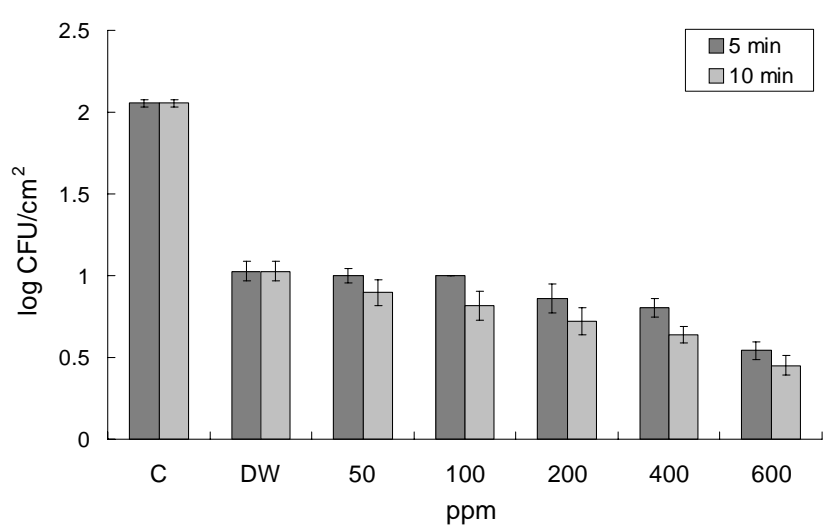

Fig. 3. Immersion tests against psychrotrophs on whole croaker dipped in acidified sodium chlorite solution for 5 or 10 minutes. 
$0.4 \log \mathrm{CFU} / \mathrm{cm}^{2}$ after 10 -min exposure to $600 \mathrm{ppm}$ ASC, while the PPC of samples treated with distilled water was reduced by $1.6 \log$ compared with the control samples.

ASC showed strong antimicrobial activity against Gram-negative, mesophilic, and psychrotrophic bacteria on whole croaker after 10-min immersion application of 600 ppm ASC. A previous study on the skin of whole salmon focusing on ASC effectiveness against total plate counts also showed that ASC dip treatment resulted in $0.43 \log \mathrm{CFU} / \mathrm{cm}^{2}$ reductions (8). In summary, this study suggests that application of ASC to whole fish may provide an effective surface disinfectant to reduce naturally occurring microbial populations on the skin of the fish. Further studies are needed to investigate the shelf life of ASC-treated whole fish and the microbiological quality of ASC-treated fish fillets.

\section{REFERENCES}

1. Bernstein RM, Schluter SF, Marchalonis JJ. 1997. Immunity. In The physiology of fishes. Evans $\mathrm{DH}$, ed. CRC Press, Inc., Boca Raton, FL, USA. p 215-242.

2. Austin B, McIntosh D. 1998. Natural antimicrobial compounds on the surface of rainbow trout, Salmo gairdneri Richardson. J Fish Dis 11: 275-277.

3. Fouz B, Devesa S, Gravningen K, Barja JL, Tranzo AE. 1990. Antibacterial action of the mucus of the turbot. Bull Eur Ass Fish Pathol 10: 56-59.

4. Spitznagel JK. 1997. Origins and development of peptide antibiotic research. In Antibacterial peptide protocols. Shafer WM ed. Human press. Totowa, NJ, USA. p 1-14.

5. Kemp GK. 2001. Potential application of acidified sodium chlorite for pathogen reduction and shelf life extension on seafood (abstract no 91-8). 2001 Institute of Food
Technologists. June 24-27, New Orleans, LA, USA.

6. Inatsu Y, Maeda Y, Bari ML, Kawasaki S, Kawamoto S. 2005. Prewashing with acidified sodium chlorite reduces pathogenic bacteria in lightly fermented Chinese cabbage. J Food Prot 68: 999-1004.

7. Beverly RL, Janes ME, Oliver G. 2006. Acidified sodium chlorite treatment for inhibition of Listeria monocytogenes growth on the surface of cooked roast beef. J Food Prot 69: 432-435.

8. Su YC, Morrissey MT. 2003. Reducing levels of Listeria monocytogenes contamination on raw salmon with acidified sodium chlorite. J Food Prot 66: 812-818.

9. Fernandes-Naglik L, Downes J, Shirlaw P, Wilson R, Challacombe S, Kemp G, Wade W. 2001. The clinical and microbiological effects of a novel acidified sodium chlorite mouthrinse on oral bacterial mucosal infections. J Food Prot 64: 276-280.

10. Omar AO, Christopher H, Sacit FB, Warf CC, Kemp GK. 2004. Effects of postchill application of acidified sodium chlorite to control Campylobater spp. and Escherichia coli on commercial broiler carcasses. J Food Prot 67: 22882291.

11. New pathogen-controlling ingredients emerge. Available from: http://www.organicconsumers.org/Irrad/newcontrols.cfm. Accessed Oct. 31, 2000.

12. Lim K, Mustapha A. 2004. Effects of cetylpyridium chloride, acidified sodium chlorite, and potassium sorbate on populations of Escherichia coli O157:H7, Listeria monocytogenes, and Staphylococcus aureus on fresh beef. $J$ Food Prot 67: 310-315.

13. Al-Nabulsi AA, Holley RA. 2006. Enhancing the antimicrobial effects of bovine lactoferrin against Escherichia coli $\mathrm{O} 157: \mathrm{H7}$ by cation chelation, $\mathrm{NaCl}$ and temperature. J Appl Microbiol 100: 244-255.

14. Hajmeer MN, Marsden JL, Fung DYC, Kemp GK. 2004. Water, sodium chloride and acidified sodium chlorite effects on Escherichia coli O157:H7 and Staphylococcus aureus on beef briskets. Meat Science 68: 227-283.

(Received November 23, 2008; Accepted December 17, 2008) 